\title{
Gyermekruházat a hétköznapi viseleten túl
}

\author{
Schmitt Csilla \\ Magyar-Japán Baráti Társaság - Szombathely
}

\begin{abstract}
A japán gyermekek életében mai napig nagy szeretpet játszik a hagyományos viselet, a kimonó. Ezen ruhák jellegzetes, üzenet értékü motivumai napjainkig őrzik jelentésüket, így lehetővé teszik a szülök számára, hogy kifejezésre juttassák újszülött gyermekükkel kapcsolatos kivánságaikat. A gyermekek az ünnepi alkalmakkor kis hercegnönek/hercegnek érezhetik magukat az alkalmi viseletben, mig a felnöttéválásra készülödö fiatalok számára lehetövé teszi, hogy megmutassák saját stílusukat, egyéniségüket. A japán oktatási rendszerben kötelezö az iskolai egyenruha, így egy ilyen alkalom az önkifejezésre értelemszerüen még fontosabb. A non-verbális kommunikáció eszközeként is alkalmazható kimonót a felnöttek is viselik. Ám a fiatalok egyéb hétköznapinak nem nevezhetö öltözetben is feltünnek az utcákon, mint a cosplay, lolita stílusok. Ezek szintén az önkifejezés eszközévé váltak, mutatva, hogy a japán kultúrában az ruházat nemcsak régen, de ma is többet fejezhet ki, mint azt a hétköznapi viseletünk teszi
\end{abstract}

Kulcsszavak: kimonó, öltözködés, szimbólum, motívum, önkifejezés

\section{Öltözködés}

Az öltözködés fontos része életünknek. Míg kezdetben a hidegtől való védelmet jelentette, a komfortérzet javítását szolgálta, az idők során minden közösségben kialakult egy információ tartalom, és a ruházat a nonverbális kommunikáció eszközévé vált.

Már a természeti népeknél megfigyelhető a törzsfönök különleges fejdísze vagy a sámán eltérő ruházata, de ahogy a társadalmi hierarchiák fejlődtek, egyre sokszínűbbé váltak ezek a kifejező eszközök is. Példaképp említhetnénk a távol keleti kultúrákban a süvegeket, melyek színükkel mutatták a hivatalnokok rangját, de a mai hadseregek rangjelzései is ide sorolhatók.

Ugyanakkor a divat is mindig újabb és újabb elemeket hozott az öltözködésbe, és az emberek társadalmi rangja ezen keresztül is tükröződött. Nem feltétlenül konkrét színekre, szimbólumokra kell gondolnunk, maga az anyag minősége, a kidolgozottság, illetve az apró részletek (aranydíszítések, csipkék) is kifejezték egy ruhaköltemény viselőjének társadalmi pozícióját. Napjainkra ez az információrendszer persze sokat egyszerüsödött. Hétköznapi viseletünkben mégis igyekszünk bizonyos trendeket követni, egyes márkák mellett letenni voksunkat. Ruházatunk azonban sokkal kevesebbet árul el rólunk.

\section{Népviselet}

Az egyes nemzetek illetve azon belül is bizonyos népcsoportok népviselete a világ öszszes részén fennmaradt. Cliffe a tradicionális ruházatot úgy definiálja, hogy „viszonylag statikus viselet, mely a szokások és társadalmi rend fenntartását szolgálja, felértékelve a múltat" (2017. 7. o.). Ezek a tradicionális ruházatok napjainkig hordozzák az információt, mely népcsoporthoz tartozik viselőjük. Hazánkban is sokan a mai napig felismernek egy matyó népviseletet, pedig sajnos e ruhák jellegzetességeit, illetve az egyéb népviseletektől való eltérő vonásait kevesen tudnák felsorolni. Valóban meg tudunk különböztetni egy palóc ruházatot egy kalotaszegitől?

A népviselet népi identitás tudatunk szerves része, fő kifejező eszköze, ezért is jelenik meg legtöbbször népzenénkkel, néptáncunkkal karöltve.

Európában általánosságban elmondható, hogy a népviselet használata „kiment a di- 
Gyermekruházat a hétköznapi viseleten túl

vatból”. Mégis örvendetes, hogy Ausztriában, Németországban fesztiválok idején sokakat láthatunk Trachtban, hiszen egy Oktoberfest elképzelhetetlen a Dirndlt viselő pincérlányok nélkül. Skóciában is jöhet szembe velünk férfi kiltben, azaz skót szoknyában. Ezen országokban az sem szokatlan, hogy üzletek kirakatában a népviselet köszön szembe velünk.

Ázsiában ez a kép már sokkal árnyaltabb. Indiában napjainkig hordanak szárit, Koreában, Japánban külön üzletág épült a kölcsönözhető népviseletre, hogy a turisták hanbokban vagy kimonóban járhassák végig a történelmi helyeket.

\section{Ruházkodás Japánban}

Japánnál maradva elmondhatjuk, hogy a kimonó (mely egyébként gyüjtőnév a japán stílusú ruhákra) mai napig a japánok ruhatárának részét képezi. Általánosnak közel sem mondható, nem elterjedt viselet, de talán nincs is olyan japán ember, aki élete során legalább egyszer ne viselte volna.

A Heian-korban (794-1185), mikor Japán először zárkózott be a külvilág elől, rengeteg japán művészeti ág indult fejlődésnek. Az ebben az időszakban kialakult viselet, melyet ma kimonóként ismerünk szintén a japán identitás kifejező eszközévé vált.

Bár szabása egyszerü, hiszen csak téglalapokból összevarrt ruháról beszélünk, mégis az apró szabásbéli különbségek, például az ujj hossza, a kiegészítők is sokat elárulnak a ruha viselőjéről. Míg a felnőttruházatnál a színek és motívumok leginkább az évszakokat követve változnak, a gyermekruhák esetében a jelentéssel bíró, szerencsehozó motívumok igen gyakoriak.

A hétköznapi ruházkodást Japánban az ország megnyitása (Meiji restauráció, 1868) óta egyre inkább a nyugati stílusú ruházat uralja. A napjainkig szigorú keretek között felnövő japán gyerekek hétköznapi viseletét azonban az iskolai egyenruha határozza meg. Felnőtteknél is elmondható, hogy rengeteg munkakör egyenruhát kíván a parkolóőrtől a felszolgálóig, de az irodai dolgozók esetében előírt fehér ing és öltöny nyakkendővel kombináció is egyenruhaszámba megy.

Természetesen az egyenruha előnyei-hátrányai egyaránt jelen vannak. Kifejezi a hovatartozást, elfedi a társadalmi különbségeket (legalább is, az adott iskolán belül), ugyanakkor nem ad teret a személyiség kibontakoztatásának, az önkifejezésnek.

A ruházatot a felnőtteknél a divat, a stílus sokban befolyásolja, de szerintem fontos szerepet játszik a gyermekek önkifejezésében is. Napjainkban szerencsére az aktuális Disney-figurák vagy pokemonok nem csak a drága minőségi ruházaton jelennek meg, így viszonylag kis költségvetéssel is boldoggá tehetjük gyermekeinket.

\section{Japán ruházat a hétköznapi viseleten túl}

Mióta megszűnt az iskolaköpeny intézménye, a szülö nálunk is fontos döntést hoz, mikor eldönti, mit ad gyermekére a közösségbe. Mit sugall a ruha, de ugyanakkor minek lesz kitéve a nap során a foglalkozások alatt, majd később, mit hajlandó a tini egyáltalán felvenni, mikor közösségbe megy.

Japánban ugyanakkor még napi gyakorlat az egyenruha. Mint már szó volt róla, nemcsak az iskolákban, de a munkahelyek többségénél is. Ennek következménye, hogy a hétköznapi ruházat jelentősége csökken, szinte csak szabadidős, illetve otthoni viseletről beszélhetünk. Ezekbe a hétköznapokba hoz színt a néhány ünnep, mikor a gyermek kimonóba bújhat. A kimonó ugyan egyszerü szabású, de színek, motívumok terén nem szab határt a fantáziának. Mindenki saját ízlésének, stílusának megfelelően válogathatja össze ruhája és kiegészítői kavalkádját. És ki ne szeretné megmutatni magát a világnak? Különösen gyerekként, vagy lázadó tiniként?

A kimonót azonban nem csak a gyerekek viselik. Egyre több végzős is visszatér diplomázáskor a kimonó és hakama összeállításhoz. Cliffe szerint a változás az egyetemekről terjed a középiskolák felé, sőt még az általános iskolák felé is. Ha az iskola politikájának nem is része, néhány diák mégis a kimonó és hakama viseletben búcsúzik az iskolától 
(2017). És az önkifejezésre Japánban nem csak a kimonó ad lehetőséget, mely kihangsúlyozza a nemzeti hovatartozást, hiszen több szubkultúrának tekinthető stílus is virágzik. Hétköznapi viseleten kívül eső ruházkodásként említhető akár a lolita vagy a cosplay is.

Cliffe több hasonlóságot sorol fel (2017) a kimonó viselők csoportja és az általa „style tribes"-nak nevezett stíluskövetők, mint a lolitások között. Először is Tokió hasonló negyedeiben tünnek fel, és már vidéken is megjelentek. Azt írja, ezek a helyek azok, ahol az 50-es években stílusos nyugati ruhákban próbáltak a fiatalok szembehelyezkedni a hétköznapok kimonóviseletével. Ma a kimonóviselők helyezkednek szembe a nyugati viselet hegemóniájával a japán viseletbe öltözéssel. Másodszor hasonló a megjelenés iránti figyelem. $\mathrm{Az}$ 50-es években, amikor a férfiaknak nem kellett volna figyelniük a megjelenésre, fiatal férfiak Ivy League stílusban ${ }^{1}$ öltözködtek és piperkőcök voltak. Odafigyeltek a részletekre, ami a kimonóviselőkre is jellemző, hisz nagy gondot fordítanak a ruházkodásra. Továbbá mindkét csoport jellegzetessége, hogy lézeng, közterületeket elfoglalva álldogál, és igényli a hegemón többség figyelmét. Úgy fogalmaz, azért öltöznek fel, hogy észrevegyék őket.

Természetesen különbségeket is felsorol. Míg a háború után a stíluskövetők többnyire a dolgozó osztályokból kerültek ki, a kimonó viselőknél nehéz osztályt definiálni, de túlnyomó részben nem munkásosztály. Magába foglal diákokat, szakmabelieket, munkásokat, és háziasszonyokat is. Átvág nem, kor, és osztálybeli kötöttségeket. Másik jelentős különbség, hogy a stíluskövetők kisajátítják a tengerentúli kultúrák ruházatát, mint például az amerikai vagy a viktoriánus angliai stílusok kölcsönzése, de a kimonó viselői saját kultúrájukra és történelmükre támaszkodnak.

Mindezektől függetlenül a fiatalok hétköznapin túli ruházkodásában bármelyiket megtalálhatjuk.

\footnotetext{
${ }^{1}$ A klasszikus darabokat kombináló egyetemista ifjúság divatja, melyet az 1950-es évek amerikai elit egyetemeinek hallgatói alakítottak ki.
}

\section{Lolita}

A stíluskövetők közé sorolhatjuk a lolitásokat. Úgy gondolják, hogy ez a Japánban kialakult szubkultúra az 1970-es évekre nyúlik vissza, de az 1990-es évekig nem terjedt el, akkor Oszakából indult útjára (Yoshinaga és Ishikawa, 2007). A stílus elnevezése Vladimir Nabokov orosz származású amerikai író 1955-ben írt, azonos címü regényére vezethető vissza. A mű a koraérett kamaszlány és a vonzerejének ellenállni nem tudó felnőtt férfi kapcsolatáról szól. A stílust mai napig fiatal kamaszok, túlnyomórészt serdülő lányok képviselik.

A lolita divatirányt erősen befolyásolja a viktoriánus stílus, de gótikairányzat is létezik. A lolita ruhák általános jellemzője a térdhoszszú, alsószoknyákkal kiegészített szoknya vagy ruha, blúz, térdig érő zoknik vagy harisnyák és a magas sarkú vagy talpú cipő. Általában minőségi anyagokat használnak, mint pamut, selyem, organza, tüll. A lolita stílus ma már számos alcsoportra bomlik (classic, sweet, gothic, wa stb.) és ezek a csoportok újabb lehetőséget kínálnak az önkifejezésre a stíluson belül is, hiszen nemcsak „cuki” de akár „punk” irányzatba is elmehet a nőiességét hangsúlyozni kívánó fiatal lány. Yoshinaga szerint a legtöbb követő 18 éves korára elhagyja ezt a stílust.

Érdekes, hogy japán megközelítésből azt olvashatjuk a weblio-n, hogy 2004-ben a „Simozuma Monogatari” hatására ismerték el a lolitát mint kortárs divatstílust ${ }^{2}$. Azt írják, egy nyugati tündérmese hősnőjének, egy premodern európai lánynak a ruháját követő design, amely főként fehér és rózsaszínű, infantilis formájú, fodrokkal és csipkével túlzottan díszített. A lány ártatlan káprázatosságát, kicsit démoni szépségét kifejező stílus, mely a képzelet motoriát használva a nyugati stílust, amellett hogy régimódi, egy teljesen új sajátosan japán értelmezéssel felruházó, a tiniket a középpontba állító utcai divattá vált. Ez a meghatározás szinte már elöítéletet fejez ki, nem devianciaként, inkább az éretlenség kifejeződéseként értelmezi a stílust.

${ }^{2}$ http://www.weblio.jp/content/ロリータ・ファッション 
Gyermekruházat a hétköznapi viseleten túl

\section{Cosplay}

Mint Simone is írja (2017. 22. o.), egyre többen és többen ismerik a cosplayt szerte a világon és rendszerint a japán otaku kultúrával azonosítják. Azonban a fiktív karakterek megszemélyesítése az amerikai sci-fi rajongóktól ered a 40-es évek elejéről és a 70-es, 80-as évekig nem is jelent meg Japánban. A terminológia „cosplay” valóban a japán származású, Takahashi Nobuyuki írótól származik, aki Los Angelesben az 1983-as Worldconon próbálta meg e kifejezéssel leírni, amit látott - „costume” és „play”.

A cosplay jellegzetessége, hogy a fiatal egy fiktív személy, anime rajzfilmszereplő, manga képregény karakter, vagy videojáték hős ruháját ölti magára. A kiválasztott ruha az adott figura személyiségét, tulajdonságait hivatott jelezni. Viselője a ruha által szimbolizált karakterrel szeretne azonosulni.

Úgy gondolom az, hogy ilyen bázisra talált Japánban összefüggésben van a már említett uniformizált viselettel, és azzal, hogy a japán fiatalok önkifejezésére csak szűk keretek közt van lehetőség. Az, hogy ezt a szubkultúrát menynyiben tekintjük devianciának szintén megközelítés kérdése. Különc hobbi, vagy valóban pszichés problémák elfedése? Nem célom ezt vizsgálni, de mint az önkifejezés eszköze, biztosan fontos elem, hisz lényege az, hogy egy - bár nem létező - személlyel szeretne azonosulni a fiatal, akinek külső, belső tulajdonságai számára vonzók. Azt gondolom, ebben az esetben nem is annyira a természetfeletti képességek a dominálók, hiszen nem igazán sci-fi-hősök megszemélyesítéséről van szó, inkább rajzolt mesehősökről. E figurák természetellenes (rózsaszín, kék stb.) hajszínei, már magukban kitünést biztosítanak a fekete hajú átlagemberek tömegéből. A bátorság, szókimondás, önfeláldozás, vagy épp csak a vad indulatok szabadon engedése, felvállalása lehetnek olyan tulajdonságok, amit a fiatal mindennapi életében nem tud kifejezésre juttatni, ám a karakter magán hordozza. Az egyén azonosulhat vele, hisz más akar lenni, még ha rövid időre is.

Az, hogy egy fiatal a cosplay vagy lolita segítségével akar kitűnni, akarja megmutatni ön- magát, és próbálja felhívni a figyelmet magára nem régi jelenség, de hagyományos formában ezt a szerepet tudja beölteni a kimonó is.

\section{Kimonó}

Míg hazánkban a népviselet csak bizonyos gyermekcsoportok, például néptáncosok életének része, a japán gyermekeket felnőtté válásukig több alakalommal is kimonóba öltöztetik.

Régen a kimonó egyértelműen mutatta viselője melyik társadalmi osztályhoz tartozik. Azonban mai napig szabásával, színvilágával, mintájával is nonverbális üzenetet közvetít viselőjéről, hisz elárulja nemét, családi státuszát, korát, árulkodik ízléséről, sőt a körülményekről is, mint évszak, alkalom. Motívumai ezen felül hordoznak további információt.

Fiúk esetében viszonylag korlátozottabbak a lehetőségek, de a hakama-haori alkalmi öltözetnél is színek, minták sokasága közül lehet választani. A fiúk által használt erőt és kitartást sugalló motívumok elmaradhatlan részei a kisfiúk viseletének, és többnyire a kimonó illetve a haori hátán jelennek meg.

Lányok esetében természetesen, mint minden kultúrában, sokkal szélesebb a paletta. Itt is játszhatunk a színekkel, motívumokkal, de itt már a ruha teljes felülete a rendelkezésünkre áll. A szerencsehozó motívumok, melyekre később még visszatérünk, itt is a kislányok ruháit jellemzik, bár a hajadonok ruháin is fel-fel tünnek. Kimondottan szép felületet biztosít egy-egy ilyen szimbólumnak a menyasszonyi uchikake (köpeny).

A női ruházatot azonban a kiegészítők is meghatározzák, további lehetőséget biztosítva az önkifejezésre. Míg a férjezett asszonyok öve általában szolíd, és a háton „kispárna” formában megjelenő taiko kötés díszíti, a lányok feltűnő, díszes brokátból készített övét különleges kötésekkel rögzítik. Gyönyörü masnikat, virág formában megjelenő díszeket láthatunk a hátukon. Kislányok esetében az alkalmi cipő talpa még csengőt is rejt, mely minden lépésnél kedvesen csilingel. Ezt tetőzik a különféle rögzítő szalagok, felső kabátok, prémek, me- 
lyek mind tovább színesíthetik az outfitet, és persze a hozzá illő alkalmi szandál a zōri.

Az európai lányok többsége is egész gyermekkorában arról álmodik, hogy hercegnőként jelenhessen meg a világ előtt, és ez általában a menyasszonyi ruhában ölt testet. Bár a farsang, majd később a bálozás szintén jó helyszín lehet. Japánban ez a lehetőség a kimonóban testesül meg, melyet az ünnepi alkalmakon utcai viseletként is büszkén hordanak. Azt gondolom, az előírt ruházat még nagyobb igényt teremt a saját ízlés kifejezésére, arról nem is beszélve, milyen az, ha egy nö hercegnőnek érezheti magát.

\section{A kimonómotívumok}

A cosplay esetében egy ruha az adott karakter tulajdonságait kívánja feleleveníteni, üzenetként átadni, a kimonó esetében a motívumok fejezik ki azt az tartalmat, amivel a szülö fel kívánja ruházni gyermekét, vagy a ruha viselője üzenni szeretne. A lolitánál azt figyelhetjük meg, hogy egy kor hangulatát idézi fel. A kimonó mindkét tartalommal bír, és mindezt a motívumai által éri el.

Mint már szó volt róla a Heian-korszak a japán kultúra virágzásának időszaka, ahol a császári udvar a béke és prosperitás időszakát élte a japán történelem egyik legbékésebb, a kultúra fejlődése szempontjából talán legjelentősebb időszaka. Ezért nem is csodálkozhatunk rajt, hogy a kimonó motívumai gyakran ezt a korszakot elevenítik fel. Mintegy visszavágyódás a boldog békeidőkre.

\section{A Heian-korszak motívumai}

Kirihata is arról ír (1993), hogy az emberek a Heian-korszakot boldog időszaknak tartották. Ide kapcsolódva 3 motívumot említ, melyek segítenek a császári család reprezentálásában. Ezek a hiōgi 'falegyező', a kaioke egy 'kagyló játékdoboza', valamint a misu, fa vagy bambusz 'roló,' mely az arcot rejti el a kíváncsi szemek elől. A kaioke egy hatszög alapú díszes doboz, melyben a Heian-korszak alatt kedvelt játék, a kaiawase kagylóit tartották. A magasabb társadalmi osztályokban a kaioke a menyasszonyi hozomány részeként szerepelt, és az udvari nemesség, vagy a feudális urak berendezéseinek is részét képezte (Nitanai, 2017).

Sok motívum utal erre az időszakra a kor legjelentősebb irodalmi alkotásán a Genji monogatari ${ }^{3}$ keresztül is. Ilyen például az ökrös kocsi, vagy annak kereke. Utóbbit Genjikerék motívumnak is nevezik, hisz "Genji világát jelképezi” (Yumioka, 2011) Nitanai szerint (2017) e kerekek reprezentálják a sors kerekének fordulását a történetben. Azt írja, amikor a Genji-guruma (kocsi) és a lopótök levelei kombinálódnak egy motívumban, a Genji monogatari Esti arcok címü részre utalnak. De ide sorolható a genjko motívum, mely a kōdō, azaz egy illatjáték ${ }^{4}$ során kialakított vonalakból álló szimbólum, ahol a létrehozható 52 lehetséges kombináció nevei mind a Genji monogatari egyes fejezet címeinek felelnek meg (az első és utolsó fejezetek kimaradnak). Persze említhetnénk sok növényt is, melyek e müben tünnek fel és kimonó motívumként is kapcsolatba hozhatók vele.

Kiemelném még a krizantémot is, hiszen e virág Japán szimbóluma. A Krizantém Trón a császár pozíciójának és a trónnak az elnevezése, és a birodalmi címer is egy stilizált krizantémvirág. A japán kultúrában egy általános motívum, amely a hosszú életet és megfiatalodást fejezi ki (Nitanai, 2017). Eredetileg egy kínai legendából eredeztethető, melyben a krizantémok közt átfolyó he-

3 Egy arisztokrata udvarhölgy, Murasaki shikibu (973 vagy 978-1014 vagy 1031) által írt tizenegyedik századi klaszszikus regény.

4 Egy Gomizuno császár (1595-1680) idején kialakult játék, melynek során öt féle füstölőből 5-5 kúpot használnak, melyből a házigazda véletlenszerűen választott öt kúpot egymás után a tủzre tesz. A játék résztvevői az illat alapján megkülönböztetik a füstölőket, és minden kúpot ábrázolnak egy vonallal. A játék célja kitalálni a különbségeket, és ha a játékosok úgy gondolják, hogy bármely két füstölő illata egyezik, összekötik az őket jelölő párhuzamos vonalakat egy horizontális vonallal. Az öt vonal különböző kombinációi által létrehozható 52 kombináció (Nitanai, 2017). 
Gyermekruházat a hétköznapi viseleten túl

gyi patak vize meghosszabbítja az életet ${ }^{5}$. A Heian-korszakban az emberek mérhetetlenül csodálták a krizantém virágokat, a Krizantém fesztiválon verseket írtak róluk és a virág szirmaival ízesített szakét ittak, remélve a hosszú életet és a jó egészséget. A Nanboku-korszak (1336-1392) során vált a császári udvar címerévé, ezáltal Japán szimbólumává.

\section{A személyre vonatkozó motívumok}

Mint szó volt róla, a kimonó lehetővé teszi a szülők számára, hogy kifejezésre juttassák újszülött gyermekükkel kapcsolatos vágyaikat, kívánságaikat. Egy adott motívum megmutatja, milyennek szeretnék gyermeküket, vagy mit kívánnak számára. Nagyon jó példa erre fiúknál a ponty, melyet Dees (2009) a kitartás, győzni akarás szimbólumaként mutat be. Egy kínai legenda áll e mögött, melyben a ponty felúszik a vízesésen és sárkánnyá válik. A motívum a teljesítmény és előremenetel metaforája (Jackson, 2002).

A teknős vagy a minogame, a 'sörényes teknős' szintén gyakran megjelenő elem. A teknős az istenek hírnöke, és jó szerencsét hoz (Jackson, 2002), de egyben a hosszú élet szimbóluma is. A minogame változat, melyen az évek során a teknős házára tapadt vízinövények körüllengik az állatot, különösen áldásos.

Tomioka azt írja (2008) az egészséges fejlödés, növekedés érdekében a császárfát, kendert, és bambuszt alkalmazzák, míg a boldog házasság motívumai a kacsa, a kettéágazó fenyő, és a kagyló, és az amulett motívumok sorát még oldalakon keresztül folytathatnánk.

Megemlíthetők azonban a nó színházhoz vagy más irodalmi művekhez köthető motívumok, melyek szintén utalásként értelmezhetők. A nó színházat önmagában a jó szerencsével párosították. Az Edo-korszakban a szamurájok ünnepségek alkalmával néztek nót. Kirihata Zeami Motokiyot (1363-1443, nó színész, és drámaíró) idézi, miszerint „a

\footnotetext{
${ }^{5}$ Ez a legenda, a Kiku-sui az alapja a Kikujido címủ hagyományos nódarabnak (Yumioka, 2007).
}

nó meglágyítja mindenki szívét, tudatát, bármely osztályba tartozik, boldogságot ad, így meghosszabbítja az életet" (1993. 145. o.).

Ilyen motívum például az oroszlán bazsarózsával, mely a Shakkyō (A kőhíd) címü nódrámát idézi, melyben az oroszlán a bazsarózsák közt táncolva ünnepli a hosszú életet, és a boldogságot (Jakson, 2002). Az oroszlán a férfi energiát és bátorságot, míg a virág a női szépséget reprezentálja. Szintén nódarab a Daru és teknős, melynek cím állatai a hosszú élet jelképei.

Az „Ise monogatarin” alapuló yatsuhashinozu motívum, azaz nyolcpallós híd írisszel, Yumioka szerint (2007) a szülők reményét fejezi ki szépség és költői talentum iránt ${ }^{6}$. Természetesen a sort itt is tovább folytathatnánk.

\section{Összegzés}

Látható, a kimonó nemcsak megjelenésén keresztül hordoz viselőjéről konkrét információkat, de motívumain keresztül további érdekes dolgokat árulhat el, arról, amit egy adott darab megrendelője vagy viselője ki szeretne fejezni. Ennek a jelrendszernek a dekódolása, természetesen a mai emberek számára sokkal bonyolultabb, mint a lolita, vagy a cosplay esetében, de egyúttal sokkal izgalmasabb is, hiszen sokrétű, szerteágazó információhalmaz árad felénk, melynek megismerése igazi kihívás.

A hétköznapi viseleten túl megjelenő ruházat úgy gondolom mindig az önkifejezés eszközeként tűnik fel, hiszen mögöttes tartalmat és viselője által kifejezésre juttatni kívánt információt hordoz, melynek értelmezése természetesen a kívülállók részére kihívást jelent.

\section{Felhasznált irodalom}

Cliffe, S. (2017): The social life of kimono: Japenese fashion past and present. Bloomsbury Academic, New York.

\footnotetext{
${ }^{6}$ Remélve, hogy Ariwara no Narihira példáját követik.
} 
Dees, J. (2009): Taishō Kimono - Speaking of Past and Present. Skira Editore S.p.A., Milano.

Jackson, A. (2002, szerk): Timeless Beauty Traditional Japanese Art from the Montgomery Collection. Textiles. Skira Editore S.p.A., Milano.

Kirihata K.(1993): Tamura collection - Wakakusashō - Kodomo no ishō. Tamurashiryoukan, Kyoto.

Nitanai K. (2017): Kimono Design - An Introduction to Textiles and Patterns. Tuttle Publishing by Periplus Editions (HK) Ltd., Hong Kong.

Simone, G. (2017): Tokyo geek's guide. Tuttle Publishing, Periplus Editions Ltd., Hong Kong.
Tomioka K. (2008): Hitome de wakaru Kimono yōgo no kihon. Kabushikigaisha Sekaibunkasha, Tokyo.

Yoshinaga M. \& Ishikawa K. (2007): Gothic E Lolita. Phaidon, New York.

Yumioka K. (2011): Kimono no monyō zukan. Heibonsha, Tokyo.

Yumioka K. (2007): Kimono to Nihon no iro Kodomo kimono. Pie Books, Tokyo.

http://www.weblio.jp/content/ロリータ・ファッシ ヨン

\section{Children's Clothes beyond the Everyday Wear}

The traditional costume, the kimono, plays until today a large role in the life of Japanese children. The typical message carrying motifs of these dresses kept their meaning until today and allow parents to express their wishes for their newborn baby. At festive occasions children can feel in their ceremonial dress like a little princess or prince and young people preparing for their adulthood are provided with the opportunity to show their own individual style. For self expression such occations play an even greater role as school uniforms are compulsary in the Japanese schooling system. The kimono, that is often used as means for non-verbal communication, is as well worn by adults. Young people, however, can in addition be seen on the streets in other not common clothes referred to as Cosplay or Lolita styles. These have also become a means of self-expression stressing that in Japanese culture clothing, not only in the past but also today, reveals more than everyday wear.

Keywords: kimono, clothing, symbols, motifs, self-expression 